\title{
On the Process of Sedentarization of Volga Bulgars
}

\author{
Fayaz Sh. Khuzin ${ }^{1}$ \\ ${ }^{1}$ Kazan (Volga Region) Federal University, Kazan, Russia \\ Correspondence: Fayaz Sh. Khuzin, Kazan (Volga Region) Federal University, Kremlyovskaya 18, Kazan, \\ Russia. E-mail: khuzinfayaz@mail.ru
}

Received: June 15, 2015 Accepted: June 24, 2015 Online Published: June 30, 2015

doi:10.5539/jsd.v8n7p68 URL: http://dx.doi.org/10.5539/jsd.v8n7p68

\begin{abstract}
The relevance of the study is determined by the need to create a more complete picture of the conversion of the nomadic peoples of Eurasian steppes, namely, the Volga Bulgars living in VIII-X centuries, to a strict sedentarization while statehood was being formed and new religion - Islam was being spread. The objective of the article is to analyze the available sources, enabling to specify the chronological framework of sedentarization of Bulgars, which at the end of IX - beginning of X centuries resulted in the emergence of stationary settlements, including cities. The multidisciplinary approach to the problem is the leading one in this article. It involves synthesis of data provided by a number of sciences in order to obtain complete information. The article presents the results of the analysis of written sources contained in the works of Oriental authors dated back to X century, archaeological and numismatic materials. The article submissions may be worthwhile in studies conducted by scholars researching Bulgars and scientists involved in researching the general issues of the history of nomadic and semi-nomadic peoples of medieval Eurasia.
\end{abstract}

Keywords: Volga Bulgars, sedentarization, stationary settlements, early city farming

\section{Introduction}

Volga Bulgaria of the X - the first third of the XIII century is one of the earliest state formations of North-Eastern Europe with a predominantly Turkic-speaking population. Russian historians got interested in it in the XVIII century (Huzin, 2001). The middle of the last century is known as the start of a rapid advancement of the Bulgarian archeology and research on the whole, The results long-lasting researches related to material and spiritual culture, economic, social, political and cultural life of the Volga Bulgaria, including the problems of interaction of the Bulgars with neighboring Finno-Ugric, Turkic peoples, Kievan Rus and the ancient kingdoms, Eastern and Western are comprehensively reflected in the second volume of the seven-volume " Stories Tatars " (History of the Tartars, 2006).

Unfortunately, earlier stages in the history of the Bulgars, relating to the period of their migration from the Eastern European steppes to the Middle Volga in the VIII-IX centuries are still poorly understood due to the lack of the sources. The researches were focused on early formation of an ethnic basis of its population based on materials of pagan burial grounds (Kazakov, 1992). Settler materials remained undetected or incorrectly assessed, which contributed to the opinion among researchers about nomadic nature of the economy and lifestyle of the Bulgars before state was formed. Moreover, in recent decades, archaeologists of Ulyanovsk and Samara discovered the traces of early settlement with a thin cultural layer and a small amount of finds, marking the beginning of nomadic lifestyle of Bulgars in the pre-state period of their history (Matveyev, 1997). However, despite the obvious evidence of the sedentarization process of the population in VIII century, the attempts to bring the chronological framework of early Bulgar period of the 60s of X early XI centuries are being taken (Kazakov, 1982, 2008).

It must be noted that in our historiography the period ("pre-state, pagan nomadic"), which began with the arrival of the Bulgars in the Middle Volga in the late VII - beginning of VIII centuries which resulted in state formation in IX-X centuries, as well as an official adoption of Islam in the year 922 is called Early Bulgarian. The emergence of the first cities and rural settlements in the Bulgarian state are dated back to the beginning or the first quarter of the tenth century according to the available sources.

The attempts made by a number of researchers (Kazakov, 2000; Rudenko, 2007; Starostin, 1999; Begovatov 2006) to present the tenth century Volga Bulgaria as a country with a predominantly pagan and nomadic 
population contradicts the sources. We have already studied the relations between Islam and paganism in the pre-Mongol culture of Bulgaria, the imaginary "pagan shrines", allegedly functioned until the era of the Golden Horde (Huzin \& Khamidullin, 2013). The pursuit of an objective conclusion about the time of appearance of permanent settlements of the Middle Volga Bulgars, generating heated debates, forced us to carefully analyze the entire body of available sources on the issue.

\section{Methodological Framework}

When analyzing the sources, we relied on methodological orientations of Russian historical science asserting the thesis of a high development of the economy and settled distinctive urban culture in large part of the steppe peoples of early medieval Eurasia, beginning with the Huns and ancient Turks, the culture of which until recently was considered to be a purely nomadic (Kyzlasov, 2006).

The following theoretical position taken by the author implies, on the one hand, the close relationship between the types of farming (agricultural, pastoral, hunting and fishing and other ones.), features of material culture, a way of life and on the other hand, the natural and geographical conditions of the region where they lived. Forest-steppe landscape and temperate continental climate of Middle Volga (especially cold winters with deep snow) did not encourage a year-round nomadic lifestyle, by on the contrary, steppe nomads converted into settled people. This evidence can be substantiated by the example ancient Magyars, who abandoned in the Lower Kama not isolated burial but a fairly large Bolshetigansky one dated back to the second half of VIII-IX centuries (Chalikova \& Chalikov, 1981). Therefore, a priori it may be assumed that almost immediately after "gaining the homeland" in the Middle Volga part of the Bulgarian population, especially the poor, gradually began to settle on the land and took up farming and crafts. The multidisciplinary approach to the problem involving synthesis of data provided by a number of sciences in order to obtain complete information promoted to the proof of this hypothesis.

\section{Results}

\subsection{The Analyses of Written Sources}

First of all, the written sources are to be analyzed. According to the Arab geographer Ibn Rust (beginning of the tenth century), whose work was written between 903-913 years, but reflects the reality of an earlier time, the majority of Bulgarians have professed Islam. There were mosques in their villages and mosques had the religious schools muezzins and imams. "Bulgars are agricultural people, - he goes on - and they cultivate all sorts of grain bread, such as wheat, barley, millet and other" (Chwolson, 1869). This information is ignored by some archaeologists (Kazakov, 2008) as it has been subjected to numerous later editions, distorting the original text. Therefore the invaluable information provided by Ibn Fadlan is worth referring to. The accuracy of this one is beyond doubt.

Ahmad Ibn Fadlan in his notable work "Notes" telling about his journey experience as a member the Baghdad embassy, visited Bulgaria in 922 and proves what Ibn Rust had written about Bulgars earlier. He says that he saw Muslims Barandzhar accounting for five thousand people, and there were mosques in this country (Kowalewski, 1956). According to the observations made by Ibn Fadlan, "their (Bulgars) food - millet, horse meat, and large amount of wheat and barley, and anyone who saw something, takes it for themselves" (Kowalewski, 1956). Ibn Rust and Ibn Fadlan indicate that the Bulgars by the beginning of the tenth century already had developed agriculture and individual cultivation. Despite the absence of any indication that they had cities, Arab writers are unlikely to have written about Muslims, nomads having no permanent settlements.

According to the sources, agriculture in addition to satisfying the domestic demand for bread, posed a significant surplus product, whichwas exported. The ancient chronicles dated back to the year 1024 run that during the famine in Suzdal Russians left for the Volga Bulgaria, "privezosha zhito (hleb) and taco ozhisha" (Complete Collection, 1962). It is clear that the recent nomads, who lacked strong skills in farming, were unable able to export grain. Long and strong traditions in this field are required for it. And the population had these traditions, as evidenced by archaeological data.

In the Eastern European steppes, as it reported in reliable sources, Bulgars appear in the V century, but rather, before that, as a part of Hun hordes (Artamonov, 1962). The first traces of settlement in the forest-steppe Don region presented by a unique yurt-shaped dwelling belonging to "people from the steppes" on the settlement Ksizovo-19 in the Lipetsk region date bak to these times (Oblomsky, 2006). It did not take them, late Huns or pro-Bulgars centuries to begin a sedentary life, when the appropriate conditions were provided. And already in the VI century Syrian writer Zachary Ritor wrote about the presence of Bulgar cities (Pigulevskaya, 1941), though this message is not supported by archeological evidence. At the end of the VI century Bulgars became 
dependent on the Western Turkic khanate, after the collapse of which in the 30s of VII century on the eastern shores of the Black and Azov Seas on the Taman Peninsula and in the Kuban region Great Bulgaria ruled by Khan Kubrat was founded. Great Bulgaria The vast majority of the population of the state was nomadic, however, remains of camps and even traces of permanent settlements, belonging to actually Bulgars, according to S.A Pletneva, are discovered by archaeologists everywhere (Pletnev, 1997).

The initial period in the early history of Volga Bulgaria until recently was associated with the arrival of the Bulgars from the Volga regions of Saltov culture at the end of VIII-IX centuries. Meanwhile, the Samara archaeologists refer the first wave of migrations of the Bulgars to the time when the Great Bulgaria of Kubrat was in decay. This is confirmed by archaeological evidences, burial mounds and ground burials of novinkovskiy type in Samara, Volga region of Ulyanovsk, which, according to the researchers, were left by Bulgars at the end of VII-VIII centuries of the first half (Matveyeva, 1997). Obviously, G.I Matveeva and S.A Pletneva, believing that representatives of novinkovskoy culture migrated to the Middle Volga region simultaneously with the migration of the Bulgar horde of Asparuh on the Lower Danube, are right (Matveyeva, 1997; Pletneva, 1997). The next migration wave of Bulgars from Don region to the regions of the Middle Volga is marked by the monuments located in Samara, Ulyanovsk regions and the Republic of Tatarstan. The most notable among them is Bolshetarhansky burial dated back to the middle of VIII - the first half of the IX century (Gening \& Khalikov, 1964). It is acknowledged that this resettlement was triggered by Arab-Khazar wars, more precisely, a major defeat of the Khazar khanate against the troops led by Marwan in 737, which resulted in the adoption of Islam by khanate (Khalikov, 1989). However, until the IX century, and even in the first half of the IX century Islam was hardly widespread among the ordinary population of the Khazars. This is evidenced by the pagan character of Middle burial of early Bulgars dated back to that time. Most researchers believe that Central Asia, in particular, Khorezm was the main area Islam was spread from (Artamonov, 1962). Archaeological excavations of recent decades illustrate a significant Islamization of khanate population, particularly in the region of the Middle Donechya, only in the second half of the IX century (Kravchenko, 2005). According to our observations, the processes of sedentarization of Bulgars and the spread of Islam were parallel.

According to S.A Pletneva, the Khazars themselves, perhaps remained nomads until the death of khanate, but other ethnic groups, including the Bulgars, Alans, Savirs, Barsils / Bersuls, i.e those tribes who migrated later to the Middle Volga, were settled and semi-settled. In VIII-IX centuries, they founded cities and fortresses, they lived not in portable yurts but in semi-dugouts and stationary yurt-shaped dwellings. The population was engaged in agriculture and viticulture, the various kinds of handicrafts and trade. The researcher pinpoints that, "the total sedentary of Khazar Khanate population and mainly agricultural nature of the economy cannot be questioned" (Pletnev, 2000). There is also no reason to believe that the Bulgars who moved to the Middle Volga-Kama land in the middle of the VIII centure returned to the nomadic way of life.

The third wave of migration from the territory of the Bulgarian Khazar Khanate occurred during the second half of the IX century and lasted almost to the beginning of the tenth century. The riots among Bulgars related to formal adoption of the new religion - Judaism by the Khazars and powerful attacks by Pecheneg tribes caused the troubled situation in the country are considered to be the reason for the new migration. There were Muslims among immigrants who found a second home in the Middle Volga. It had already been mentioned that Ibn Rust and Ibn Fadlan, fixing them up to 922 year reported about it. These Bulgars brought Runic writing, used along with the Arabic script to XI-XII centuries (Kyzlasov, 1990).

The reference monument of the Volga Bulgars of this time is the famous burial Tankeevsky, which began operating in the second half of the IX century. It is the largest one among the early medieval cemeteries in Eastern Europe (Khalikova \& Kazakov, 1977). It is clear that the nomads could not leave such a huge necropolis, containing, according to preliminary estimates, more than 5,000 tombs, later of which were committed according to Muslim rites. As a rule, single graves, scattered across vast steppes or inlet in the grave mounds from the Bronze Age belonged to nomads. In the district of Tankeevsky burial a significant amount of the settled population lived. Unfortunately, their settlements have not been discovered yet.

The fact that the fixed settlement had already appeared, at least from the end of IX century, can be supported by the fact of mintage by Bulgarian Khan Jafar ibn Abdallah, who had already adopted Islam (his pagan name Almush) in the years 902-908 (Ioannina, 1962).

Funeral ceremony and rich clothing of Tankeevsky population are largely similar to Bolshetarhanskiy one, but also have their own pecularities. It is mainly indicated in ceramics and female ornaments characteristic to the culture of the population of the Upper Kama, and is undoubtedly the result of the penetration of the Finno-Ugric strongly Türkicized tribal groups into the Middle Volga (Kazakov, 1992). These tribes on their former territory 
led sedentary lifestyle, and there is no reason to believe that in the medium of Bulgars they adopted the nomadic life. The last wave of the Bulgar population relocations from areas of Podonye refers to the end of the tenth century (Kazakov, 1992). It is logical to link the cause of the migration to the collapse of the Khazar khanate in the 960-970's. According to some researchers it was the time of final formation of the Bulgar statehood, accompanied by mass sedentarization of nomadic population, the foundation of rural (agricultural) and urban (trade and craft) settlements with material culture characteristic to the next XI - beginning of XIII centuries.

Meanwhile, new archaeological discoveries of recent years undoubtedly indicate the beginning of sedentarization of Volga Bulgars long before their state was founded at the turn of IX-X centuries. G.I Matveeva, who studied novinkovskiyi monuments situated in Samara Volga region regarded them as remains belonged to ancient Bulgars of the first wave of relocations and, based on the number of finds from burials including the plow cutter believed that sedentarization began in the first half of the VIII century (Matveyeva, 1997). A similar conclusion was reached by D.A Stashenkov who studied duffel complex of Proletarian settlement on the Samara Bend: "A significant number of objects, marking the beginning of the process of sedentarization of the nomads of the Khazar time were discovered in the region at the settlement monument" (Stashenoks, 1999).

In the mid-1980s, Y.A. Semykin (1996) studied Abramovskoye settlement of the VIII century in the Ulyanovsk region. The materials of early Bulgar time played a significant part in the culture of this settlement. Among the finds the fragment of a pitcher is an object of a great interest. The author finds direct analogies in the ceramic collection of Bolshetarhanskiy burial dated back to the second half of VIII and the first half of IX centuries. Metallographic analysis of iron objects presented the technology characteristic for blacksmithing complex from Great Tarhan. According to the researcher, a medieval complex of Abramowskoye settlement "is a short-term seasonal settlement of early bulgar population group with a number of steelworkers conducting the experiments on receiving iron on the basis of the local extraction of iron ores" (Semykin, 1996). The research conducted by Semykin on the fortified settlement "Devil's town" proved to be efficient. Early Bulgar ceramics having close analogies in the same Bolshetarhanskoye cemetery was discovered in these finds. Contrary to popular notions, the researcher believes that in the VIII century there were settlements on the territory of the Middle Volga region, where Bulgarians lived all year round (Semykin, 1996).

Even in 1954 T.A Khlebnikova (1984) carried out excavations of Malopaltsinskoye Villages in the Ulyanovsk region. The finds of these excavations for some reason are ignored by the advocates of late sedentarization of Bulgars. Ceramic complex of the monument is very peculiar. Stucco crockery make up $60 \%$ of the total number of findings. It is worth noting that none of the known excavations of Bulgar settlements contains such a large percentage of archaic crockery. Apparently, therefore, G.A Fedorov-Davydov, referring to the percentage of stucco and ceramic pottery as the most important chronological markers in the dating of the settlement, was inclined to refer Malopaltsinskoye Villages to the VIII-X centuries (Fedorov-Davydov, 1962). The archeologist conducted the excavation dated the settlement to the X-XI centuries, at the same time pointing out that the the settlement was founded at the turn of the IX-X centuries. It seems, however, G.A Fedorov-Davydov was right. The main group of stucco ceramics is compared with nomadic utensils of saltovo-mayatsky culture of Don region, especially brightly presented in the Khazar fortress Sarkel (Khlebnikov, 1984). It is easy to notice a certain similarity with a group of Malopaltsinskoy ceramic utensils and Bolshetarhanskoye burial and Sevryukaevskoye II Villages (Gening \& Khalikov, 1964; Ermakov \& Matveeva, 2002). There is every reason to believe that Bulgars,recently moved from the southern steppe regions and starting to become sedentary lived in these settlements.

Apart from the abovementioned monuments, archaeologists discovered dozens of locations, the individual items in the layers of the pre-Mongolian settlements, testifying about the process of sedentarization occuring in VIII-IX centuries throughout the territory of the early settlements of the Bulgars. Two Villages studied at the end of the last century in the northeastern Bulgarian fortifications in the lower reaches of the Maloierusalimskoye ravine are of great interest (Starostin, 1993). The materials of both monuments are of exceptional importance for the study of issues related not only to the origin of the city of Bulgaria, but also the time of foundation of stationary settlements of the Volga Bulgars. The Earliest one is Maloierusalimskoe II settlement, located on the slopes of the left bank of the ravine. The remains of four dwellings of rectangular shape ( $3.6 \times 2.7 \mathrm{~m})$, household pits, storage, grain storage, pole-holes were discovered in the cultural layer capacity of about $20-30 \mathrm{~cm}$. The iron knives, an ax, a scythe-salmon, pieces of millstones, glass beads, copper bracelets, bone artifacts were found. The pottery and ceramic stucco makes up the largest part of the finds. In the first group of dishes the pitcher with the extension of the body at the bottom, similar to jugs of early Bulgar cemeteries is woth mentioning. The dishes, typical of the Finno-Ugric monuments of the Upper Kama region make up the numerically dominant group of modeled ceramics. Some vessels have southern, Saltovo-Mayatsky origin (Starostin 1993). Numismatic 
finds, Samanid dirhams of 5 copies, are rare for cultural layers of settlements. The earliest of them were minted in the year 894/895. The coin dated back to $898 / 899$ years was discovered in one of the houses. Later coins are dated back to 913-932 years (Starostin, 1999). Based on the above materials, P.N Starostin dates the existence of left-bank Maloierusalimskogo settlement to the first third of the tenth century. It seems to me that at a specified time, the settlement was still functioning, but the appearance of it refers to an earlier time, most likely to the second half of the ninth century. It is not entirely correct to refer to the findings of coins when identifying the datings of settlements, because the coins could get into the cultural layer later, not at the time of $f$ settlement foundation.

Izmerskoe settlement, huge in size (60 hectares) and Semenovskoe settlements located just $3 \mathrm{~km}$ away have been studied by archaeologists since the 1960s. The works were mostly oriented on conservation and collecting the surface material. The abundance of finds from the cultural layer of settlements of Kuibyshev reservoir, especially trade items (tens of scales and their parts and hundreds of different kinds of weights, a large number of coins, including Western ones) and the jewelry items is impressive. E.P Kazakov dates the functioning of these trade and craft settlements to the last quarter of the X-XI centuries. However, there is reason to date the time of their occurrence to the first half of the tenth century. The Ceramic Collection, according to the publications, contain, along with the Bulgarian pottery, glassware group stucco of Saltovo-Mayatski and the Ural-Kama sources. Certain types of glass beads, pads, pendants, buckles and other items date back to the whole X-XI centuries, but some of them were out of use by the middle of the tenth century (Kazakov, 1991), thus they are older. Among numismatic finds from the Izmerskoye settlement Samanid's dirham dating back to 902-908 is worth mentioning (Kazakov, 1991). The earlier coin - a silver dirham from Herat, minted in 814 was also found (Begovatov, 1999). These findings clearly illustrate that in the first quarter of the tenth century Izmerskoe and Semenov trade and craft settlements had already been successfullyfunctioning.

Bulgarian, Suvar and Bilyarsk settlements are classical monuments, the time of foundation of which, in my opinion, can not be called into question. Premongolian layers of each one contain almost identical, chronologically similar material. Bolgar and Suvar are mentioned as large cities with up to 10 thousand inhabitants in written sources of the first half of the tenth century, starting with the 930's (Huzin, 2001). Judging by some objects found on the territory of Bilyarsk settlement, it appeared likely, on the site of earlier settlements, which existed at the end of IX - beginning of X century. It should be noted that the number of the molded dishes in culture bed of Bilyar (in average 3-5\% of total ceramics) exceeds the Suvar one (less than 1\%). There are things (arrowheads, beads, jewelry made of non-ferrous metals, etc.) that existed in the IX - beginning of X centuries among the findings of the lower horizon of the cultural layer (Khuzin, 2001). It is worth noting that the earliest date of foundation of Bulgaria and Suvar are not doubted, even by advocates of late sedentarization Bulgars, but Bilyar is excluded from the list of early cities, probably because that it is not mentioned in the works of the Eastern writers of the first half of the tenth century.

\section{Discussions}

Historical content of early bulgar period was discovered by Professor of Oriental Kazan Pedagogical Institute V.F Smolin in 1920. "The initial period of the Bulgar culture in the Volga" was identified by him as the time of establishing of state institutions, the gradual transition from a predominantly nomadic lifestyle to a settled way of life, the appearance of the first fixed settlements, formation of a kind of culture with considerable local Finno-Ugric and oriental elements. According to V.F Smolin, early Volga Bulgars, who were knowledgeable enough in agriculture and crafts, "replace their steppe yurt tents with wooden houses, the occasional encampments are replaced with the cities, fortified by walls and moats." At the beginning of the tenth century, the city "Bulgar within the suburbs of modern Bilyarsk" appears and becomes the capital city, and Suvar city appears, the heyday of which accounted for the second, pre-Mongol period (Smolin, 1925). This logical concept, then was proved by archaeological materials, and was unanimously adopted by researchers and still dominates in the historical and archaeological literature.

In light of these arguments, the opinion expressed by E.P Kazakov and his followers about the nomadic nature of the Bulgarian society of the tenth century raises many objections (Kazakov, 1992; Starostin, 1999; Begovatov, 2006; Rudenko, 2007). E.P Kazakov believes that in the 60 years of $X$ century the muslim groups, "the descendants of the "black Bulgars" of Batbaya moved from the Azov Sea to Middle Volga from Khazariya which was dying under the blows of the Pechenegs and Svyatoslav. They are believed to have brought elements of culture (the post-antique pie dishes, development of handicrafts, agricultural implements), unknown in the Volga Bulgars, but from the ninth century typical of developed areas Saltovo-Mayatski culture. Since that time, even the rural cemeteries become Muslim, and the culture of the country acquires the features that were characteristic to the entire pre-Mongol period" (Kazakov, 1999). Thus, according E.P Kazakov, the population of Bulgaria until 
the early 960's was not engaged in agriculture or crafts and continued to worship their pagan gods. It is strange, but the power Almush, the ruler of the emerging state of Bulgars had, is compared "with the power of the Frankish King Clovis at the beginning of the VI century" (Kazakov 2000).

The concept offered by E.P Kazakov, was supported, however, without serious argument, by P.N Starostin (1999), E.A Begovatov (2006) and K.A Rudenko (2007), and this concept is called into question. The foremost objection is that the existence of nomadic state in the natural and geographical conditions of the Middle Volga and the Lower Kama area is simply impossible. For two centuries, since the advent of the Volga Bulgars, and before the emergence of their state, the sedentarization, accompanied by intensive development of agriculture and the development of various sectors of trade was in process. The letter written by Almush Khan, son of Shilka / Jafar ibn Abdallah, addressed to the Baghdad Caliph Muktadir, contained a request to help him, the governor of the Bulgars, to build a strong fortress, "in order to be protected against the kings, his enemies" (Kowalewski, 1956). According to A.H Khalikov and F.S Khuzin, this fortress was built, and it was located on the site of ancient settlement of Bilyarsk on the Small Cheremshan river reminding the "village"of the Hun leader Attila, some cities of Khazar Khanate, including its capital Itil, the capital cities of the First Bulgarian Kingdom Pliska and Preslav on Dunabe (Khalikov, 1989; Khuzin, 2001; History of the Tartars, 2006).

Researchers are well aware of the difficulties of dating of early settlement layers, especially multilayered ones. They are almost ruined and contain a small number of finds that complicates the settlements foundation time. This situation is typical of the early sites of the Volga Bulgaria.

\section{Conclusion}

Thus, we do not see sufficient grounds for the expansion of the upper chronological border of early bulgar period almost until the end of the tenth century. The end of the IX century and the first quarter of the tenth century can certainly be considered as the final stage of sedentarization of Volga Bulgars and the mass foundation of permanent towns. The sedentarization process was accompanied by dramatic changes taking place in all spheres of life of the Bulgarian population. They are related mainly to the formation of a new social order, the development of advanced technologies in the crafts, the advent of improved implements of tillage, harvesting and processing the harvest in agriculture, etc. The climate conditions, more severe than in the south, forced people to replace yurt-shaped dwellings by carcass houses. And finally, the role of Islam, cultural contacts with neighboring nations, East and West can not be denied in the formation of the pre-Mongolian cultural identity.

\section{Acknowledgments}

The work is performed according to the Russian Government Program of Competitive Growth of Kazan Federal University.

\section{References}

Artamonov, M. I. (1962). The History of Khazars. Leningrad: The Publishing House of state Hermitage.

Begovatov, Ye. A. (1999). Abu Rayhan al-Biruni about Volga Bulgaria, country of isu and yura. Finno-Ugrica, 1(3), 29-37.

Begovatov, Ye. A. (2006). Trade and craft centers of Volga Bulgaria at the turn of the X-XI centuries. (based on II Bilyarsk Villages). Production centers: Sources, "road", the area of distribution (141-146). Saint-Petersburg.

Chalikova, E. A., \& Chalikov, A. H. (1981). Altungarn an der Kama und im Ural: Das Gräberfeld von Bolschie Tigani. Budapest.

Chwolson, D. A. (1869). News about Hozars, Burtases, Bulgaria, Magyars, Slavs and Rousseau by Abu Ali Ahmad bin Omar Ibn Dust. St. Petersburg.

Complete Collection of Russian Chronicles. T. 1. Laurentian Chronicle and Suzdal annals of academic list. (1962). Moscow: Eastern literature Publishing.

Ermakov, S. F., \& Matveeva, G. I. (2002). Sevryukaevskoe settlement. Issues of ancient history of the Volga-Kama (46-53). Kazan.

Fedorov-Davydov, G. A. (1962). Tigashevskoe settlement. (Archaeological excavations in 1956, 1958 and 1959.). Materials and research on the archeology of the USSR, 111, 49-89.

Gening, V. F., \& Khalikov, A. K. (1964). Early Bulgars on the Volga (Bolshetarkhanskiy burial). Moscow: Science.

Huzin, F. S. (2001). Bulgarian city in X - the beginning of XIII century. Kazan: Publishing house "Master Line". 
Kazakov, E. P. (1982). About the archaeological study of early bulgar period. New in archeology and ethnography of Tatarstan (29-37). Kazan.

Kazakov, E. P. (1991). Bulgarian village of X-XIII centuries, the lower reaches of the Kama River. Kazan Tatar publishing house.

Kazakov, E. P. (1992). The culture of early Volga Bulgaria. Moscow.

Kazakov, E. P. (2000). About the statehood of Volga Bulgaria in IX-XI centuries. Acute problems of the history of the statehood of the Tatar people (21-27). Kazan.

Kazakov, E. P. (2008). About the earlier date of pre-Mongol capital cities of the Volga Bulgaria. Finno-Ugrica, $11,34-39$.

Khalikov, A. Kh. (1989). Tatar people and their ancestors. Kazan.

Khalikova, T. A., \& Kazakov, E. P. (1977). Le cimetiere de Tankeevka. Les ansiens hongrois et les ethnies voisines a l'Est. Budapest.

Khlebnikoa, T. A. (1975). Early Bulgar. Soviet archeology, 2, 120-132.

Khuzin, F. S., \& Khamidullin, B. L. (2013). About the relationship between paganism and Islam in pre-Mongol culture of Volga Bulgaria. Literature and Culture, 1(31), 214-221.

Klebnikova, T. A. (1984). Pottery monuments of Volga Bulgaria. On the issue of ethnic and cultural composition of the population. Moscow: Nauka.

Kovalevsky, A. P (1956). Ahmad Ibn Fadlan book about his journey to the Volga in $921-922$ years. Kharkov.

Kravchenko, E. E. (2005). The Muslim population of the middle reaches of the Seversky Donets and the spread of Islam in Eastern Europe in the Khazar time. Steppes of Europe in the Middle Ages. 4. T. Khazar time (153-186). Donetsk.

Kyzlasov, I. L. (1990). Ancient Türkic runic writing of Eurasia. Moscow.

Kyzlasov, L. R. (2006). Urban civilization of the Middle and North Asia. Moscow.

Matveeva, G. I. (1997). Cemeteries of early Bulgarians on the Samara Bend. Samara.

Oblomsky, A. M. (2006). Yurt-shaped construction of the V century BC in the Upper Don region. Medieval archeology of the Eurasian steppes (40-52). Moscow; Yoshkar-Ola.

Pigulevskaya, N. V. (1941). Syrian sources on the history of the USSR. Moscow. Leningrad: Publishing House of the Academy of Sciences of the USSR.

Pletneva, S. A. (1997). Ancient Bulgarians in Eastern steppes. Tatar archeology, 1, 31-60.

Pletneva, S. A. (2000). Essays on Khazar archeology. Moscow: Jerusalem.

Rudenko, K. A. (2007). Volga Bulgaria in the XI - beginning of XIII centuries: settlements and material culture. Kazan.

Semykin, Y. A. (1996). On the question of the settlements of early Bulgars on the Samara Bend. The cultures of Eurasian steppes of the second half of I millennium BC (66-82). Samara.

Smolin, V. F. (1925). The archaeological sketch of Tatrepublic. Materials for the Study of Tatarstan, 2, 5-70. Kazan.

Starostin, P. N. (1993). The early settlement on the right bank of the Small Jerusalem ravine in Bulgaria. Archaeology of Volga Bulgaria: problems, searches, solutions (53-63). Kazan.

Starostin, P. N. (1999). On early Bulgaria. The scientific legacy of A.P Smirnov and modern problems of archeology of the Volga-Kama (99-101). Moscow.

Stashenkov, D. A. (1999). Samara borderlands: the problem of interaction between nomadic and settled worlds of the Middle Ages. The scientific legacy of A.P Smirnov and modern problems of archeology of the Volga-Kama (75-77). Moscow.

The history of the Tatars from the ancient times in seven volumes. T. II. Volga Bulgaria and the Great Steppe. (2006). Kazan.

Yanina, S. A. (1962). New data on the coin mintage of Volga Bulgaria of X century. Materials and researches on the archeology of the USSR, 111, 179-204. Moscow. 


\section{Copyrights}

Copyright for this article is retained by the author(s), with first publication rights granted to the journal.

This is an open-access article distributed under the terms and conditions of the Creative Commons Attribution license (http://creativecommons.org/licenses/by/3.0/). 